\title{
LIABILITY FOR LEGAL EXPENSES CAUSED BY TAX CLAIMS INCONSISTENT WITH THE CONTRACT IN THE SALE OF A BUSINESS
}

In the sale of a business, the seller wants to receive capital gains treatment under federal income tax law, while the buyer wants to allocate as much of the purchase price as possible to deductible items. One item of negotiation is the covenant not to compete, since any money paid for it is taxable as ordinary income to the seller ${ }^{1}$ and can be amortized by the buyer. ${ }^{2}$ The seller's complaint in Stern \& Co. v. State Loan \& Fin. Corp. ${ }^{3}$ was based on the buyer's claim of a deduction for a covenant not to compete when no part of the purchase price was allocated to the covenant in the contract. The Stern court held the buyer liable for legal expenses and fees that the seller incurred defending its claim to capital gains treatment against a resulting Internal Revenue deficiency assessment.

Plaintiff Stern sold the capital stock of its wholly owned loan companies and agreed not to compete in the small loan business for five years. The contract provided that the buyer, State Loan, was to pay 2,500,000 dollars for the capital stock and assume the liabilities of the acquired loan companies. No part of the purchase price was specifically allocated to the covenant not to compete. Stern reported the profits from the transaction as capital gains from the sale of stock. The return was audited by the Internal Revenue Service in 1958 and accepted without question. On its return, defendant State Loan claimed that the difference between the book value of the stock and the total purchase price was payment for the covenant not to compete.

In 1959 the IRS disallowed State Loan's deduction and assessed a deficiency, claiming that the buyer had purchased nondeductible good will. 5 Two years later, while State Loan's case was still pending, the IRS re-

1 E.g., Hamlin's Trust v. Commissioner, 209 F.2d 761, 765 (10th Cir. 1954); Beal's Estate v. Commissioner, 82 F.2d 268, 270 (2d Cir. 1936).

2 E.g., Gazette Tel. Co., 19 T.C. 692 (1953), aff'd, 209 F.2d 926 (10th Cir. 1954); see cases collected in 4 Mertens, Federal Income Taxation $\$ 23.68$, at $154 \mathrm{n} .31$ (rev. ed. 1960).

3238 F. Supp. 901 (D. Del. 1965).

4 State Loan had an alternative theory to justify the deduction which was consistent with Stern's claim to capital gains treatment for all of its profits. See notes 41-42 infra and accompanying text.

5 Goodwill is an intangible asset which represents the ability of a business to earn more than the normal rate of return on its investment. EASTON \& NEWTON, Accounting and the ANalysis of Financial Data 318 (1958). The acquisition of goodwill in the purchase of a business is not deductible. Treas. Reg. $\$ 1.167$ (a) -3 (1956), as amended, T.D. 6452, 1960-1 CuM. BuLI. 127. However, goodwill is a capital asset and when sold gives rise to capital gains treatment. Rodney B. Horten, 13 T.C. 143, 149 (1949). A covenant not to compete is often necessary to protect goodwill since it prevents competition by the seller-the individual who originally developed the goodwill. 
opened Stern's tax return and assessed a deficiency, contending that the seller had received money for the covenant not to compete. Stern then sued State Loan, seeking a declaratory judgment that the buyer had breached the contract by claiming the deduction and an injunction to prevent State Loan from contending in the Tax Court that it had paid for the covenant not to compete. The court denied summary judgment and stayed further action until the IRS proceedings involving the parties ended. ${ }^{6}$ Those proceedings were terminated before trial: the seller retained all of its capital gains treatment and the buyer was allowed to amortize, for the tax year in question, one-fourth of the amount that it had originally claimed as a deduction. Stern then sued to recover from State Loan the expenses and attorney's fees incurred in its litigation with the IRS. The federal district court held that the buyer's action in claiming the deduction was a breach of contract which entitled the seller to compensation for the expenses that it had incurred. The court reasoned that the contract's reference to the purchase price as the price of the stock and the absence of a specific allocation ${ }^{7}$ to the covenant indicated that all of the money was paid for the stock. On the theory of an implied promise that neither party will do anything to deprive the other of the benefit of a contract, ${ }^{8}$ the court held that the buyer had implicitly agreed not to jeopardize the seller's right to treat all of the purchase price as the price of the stock; ${ }^{9}$ the buyer's

6 Stern \& Co. v. State Loan \& Fin. Corp., 205 F. Supp. 702 (D. Del. 1962). The court also denied defendant's motion for dismissal. Summary judgment was denied on the ground that factual issues regarding the terms of the contract could not be decided solely on the evidence presented in the briefs and affidavits. Id. at 708-09.

7 The inclusion or exclusion of a specific money allocation to the covenant not to compete seems to be a dominant factor in the IRS's and the Tax Court's determination of the tax treatment of covenants not to compete. See note 14 infra. This reliance may be misplaced in light of the likelihood that the parties may purposely leave a contract vague as to the points on which they cannot agree. Each party might reason that, in the covenant situation, the absence of an allocation leaves each party free to claim the tax treatment most favorable to itself.

8 Manners v. Morosco, 252 U.S. 317, 326-27 (1920) (author of play denied right to sell motion picture rights which would injure owner of the stage rights); Olsen v. Sinclair Oil \& Gas Co., 212 F. Supp. 332 (D. Wyo. 1963) (implied promise not to destroy value of property by draining oil through well on adjoining land) ; Coast Cities Coaches, Inc. v. Whyte, 130 So. 2d 121 (Fla. Ct. App. 1961) (purchaser of bus company not permitted to resell it to county where original owner could not be paid from revenues as provided in the first contract); Elliot v. Pure Oil Co., 10 Ill. 2d 146, 139 N.E.2d 295 (1956); Willingham v. Bryson, 294 S.W.2d 421 (Tex. Ct. App. 1956) (lessees had obligation to develop oil lease so that lessor could get benefit from the lease). See generally 5 Williston, Contracts $\$ 670$ (3d ed. 1961).

${ }^{9}$ It is interesting to note that the court held that State Loan's breach was of an agreement not to jeopardize Stern's right to treat the purchase price as the price of the stock. This right is important only for tax purposes. But it appears that the court was trying to avoid an explicit statement that the parties had bargained for particular tax consequences. See the court's treatment of State Loan's letter of August 30 to Stern, notes 30-32 infra and accompanying text, in which State Loan indicated that Stern's profits would be capital gains. $238 \mathrm{~F}$. Supp. at 904 . The court held that this letter was part of the contract, $i d$. at 912 , but said that Stern's rights did not depend upon this representation of the tax consequences since Stern relied on its own lawyer's advice. Id. at 914. Instead the court construed the letter as an indication that the parties agreed that the purchase price was the price of the stock. Id. at 913 . The court may have chosen this approach to avoid a holding that tax benefits can be bargained for, and such agreements are enforceable. While the language of the opinion avoids such a conclusion, it is inherent in the holding. 
contention that it was entitled to the deduction breached the contract because it meant that the buyer was claiming that part of the money had been paid for the covenant. ${ }^{10}$

Unfortunately, the court in reaching its decision did not face an issue crucial to the case: whether expected tax benefits resulting from the inclusion or exclusion of a covenant not to compete should be an enforceable part of a contract.

Congress has deliberately made the tax consequences of some transactions-for example, the payment and receipt of alimony under sections 171 and 215 of the Internal Revenue Code-dependent upon the form of the transaction. ${ }^{11}$ By so acting, Congress apparently recognized that the choice between alternative methods of setting up the transaction would be based on tax considerations and implicitly sanctioned the effect this choice might have on tax revenue. ${ }^{12}$ In the absence of a congressional determination that taxpayers may minimize their tax burdens by changing the form of the transaction to include a covenant not to compete, the substance of the transaction should be the dominant factor in determining its tax consequences. In fact, the special tax treatment given covenants not to compete is the result of a judicial recognition of the particular characteristics of the covenant transaction; ${ }^{13}$ the tax consequences of the transaction are viewed as flowing from its economic nature. The Tax Court recognizes this when it assesses the validity of claims for tax benefits in transactions involving covenants not to compete. Ordinarily the Tax Court will determine the tax liabilities of the parties on the basis of the treatment given the covenant in the contract.14 However, if it is proven that the seller is incapable of

10 The damages incurred by the seller were caused by the buyer's claiming tax treatment inconsistent with the seller's claim. See 238 F. Supp. at 914-15. The court stated that these damages were foreseeable. Id. at 915. An examination of the cases dealing with the inconsistent tax treatment of covenants not to compete indicates that both parties are often involved in litigation with the IRS over the proper tax treatment to be given the transaction. See note 26 infra.

11 Ordinarily, alimony payments are included in the wife's gross income, INx. REv. CODE of 1954, \$71 (a), and deductible by the husband, INT. REv. CODE OF 1954, \$215. However, if the parties agree to a lump sum settlement, that amount is not considered taxable income to the wife, INT. REv. CODE of 1954, $\$ 71$ (c) (1), and is not deductible by the husband, INT. REv. CODE of 1954, \$215. See BrtTker, Federal INCOME ESTATE AND GIFT TAXATION 182-83 (3d ed. 1964).

12 Obviously, a husband in a high tax bracket would prefer to have a deduction for his alimony payments. If his exwife is in a lower tax bracket, the total amount paid in taxes would be less than if he had paid the tax.

13 The rationale for treating payments received for a covenant not to compete as ordinary income is that if money received for work performed is ordinary income, so is money received for not working. Salvage v. Commissioner, 76 F.2d 112, 113-14 (2d Cir. 1935), aff'd, 297 U.S. 106 (1936). The rationale for permitting the amortization of payments made for covenants is that the buyer has purchased a valuable asset-the freedom from certain types of competition. See Farmers Feed Co., 17 B.T.A. 507, 551-54 (1917). The extent to which intangible business assets may be depreciated is treated in Treas. Reg. $\$ 1.167$ (a) -3 (1956), as amended, T.D. 6452, 1960-1 Cun. Bull. 127.

14 See Barran v. Commissioner, 334 F.2d 58, 61-64 (5th Cir. 1964); Yandell v. United States, 315 F.2d 141 (9th Cir. 1963) (per curiam); Annabelle Candy Co. v. Commissioner, 314 F.2d 1 (9th Cir. 1962) ; Fulton Container Co. v. United States, 
competing, $^{15}$ or that the covenant was inserted without negotiation ${ }^{16}$ or merely as a means of lessening a tax burden, ${ }^{17}$ the Tax Court will go beyond the contract to the underlying economic nature of the transaction and tax it accordingly. 18

It is in the interest of both the Government and the public that taxes be assessed fairly, for valid economic reasons, and against the proper party. Determining the placement of the tax burden solely from contract terms may lead to inequities for individual taxpayers, ${ }^{19}$ and tends to weaken public confidence in the tax system itself. Since our tax structure is one of self assessment, the value of having revenue payments based on economic reality ${ }^{20}$ is apparent. On a more immediately practical level,

64-2 U.S. Tax Cas. 19635 (D. Cal. 1964) ; Van Kirk v. United States, 63-1 U.S. Tax Cas. I 9277 (D. Ore. 1963) ; Betty W. Crissey, 20 CCH Tax Ct. Mem. 947 (1961).

The courts have articulated two reasons for relying on the treatment given the covenant in the contract: "The tax avoidance desires of the buyer and seller in such a situation are ordinarily antithetical, forcing them, in most cases, to agree upon a treatment which reflects the parties' true intent with reference to the covenants, and the true value of them in money." Ullman v. Commissioner, 264 F.2d 305, 308 (2d Cir. 1959). Another court stated that: "Such a result gives certainty to the reasonable expectations of the parties and relieves the Commissioner of the impossible task of assigning fair values to good will and to covenants." Schulz v. Commissioner, 294 F.2d 52, 55 (9th Cir. 1961).

A taxpayer seeking tax treatment inconsistent with the contract must introduce strong proof to overcome the declaration of the parties. Barran v. Commissioner, supra at 63 ; Ullman v. Commissioner, supra at 308 . The presumption that the contract expresses the true intent of the parties has made specific allocation, or lack of it, the dominant factor in determining the tax treatment of covenants. See Rogers v. United States, 290 F.2d 501 (9th Cir. 1961) (per curiam), upholding the trial court's refusal to look beyond the contract terms, and Annabelle Candy Co. v. Commissioner, supra at 4 , in which the plaintiff unsuccessfully contended that if a covenant had value, some allocation had to be made to it even if no allocation appeared in the contract. But see notes 15-17 infra and accompanying text.

Despite some inequities for certain taxpayers this approach may be justified on the grounds that the competing tax interests of the parties will produce a reasonable tax treatment and that it is administratively impossible for the IRS to determine the proper allocation in all cases. But cf. note 7 supra.

15 Max J. Epstein, 23 CCH Tax Ct. Mem. 1167, 1168-69 (1964) (seller was seventy-four years old, blind, and had a heart condition); Andrew A. Monaghan, 40 T.C. 680,686 (1963) (seller did not intend to operate the same type of business and was ill).

16 John W. Shleppey, 22 CCH Tax Ct. Mem. 793, 796 (1963) (total sale price set without reference to the covenant); Sidney Alper, 15 CCH Tax. Ct. Mem. 1415, 1417 (1956) (covenant was not negotiated as a separate item).

17 Fox \& Hounds' Inc., 21 CCH Tax Ct. Mem. 1216, 1226, 1228 (1962) (covenant worthless and inserted solely for tax purposes) ; Harry Shwartz, $19 \mathrm{CCH}$ Tax Ct. Mem. 1276, 1280-81 (1960) (covenant unilaterally inserted by buyer for tax purposes). 18 See also Higgins v. Smith, 308 U.S. 473, 477-78 (1940).

10 See cases cited notes 15-17 supra. The taxpayers in those cases would have paid substantially different taxes if the contract rather than the economic reality of the transaction, had been the determinative factor in the tax treatment of covenants not to compete.

20 "Economic reality," as used in this context, must be defined as that assessment of economic factors which the tax authorities and tribunals, had they all the facts before them, would ultimately make. The crucial factor which makes covenants not to compete economically relevant is the possibility of competition by the seller which would impair the value of the purchase. Absent the possibility of competition the covenant has no value, and hence no special tax treatment should be accorded it.

Defining economic reality in terms of the tax authorities' conclusions is necessary because it is on them that the outcome of cases like Stern turns. To the extent that such assessments are "incorrect" the remedy lies in direct appeal or statutory reform, not in the contrary determination of a nontax court in a connected case. 
the Government has a valid interest in insisting that the tax treatment be consistent with economic reality, for the tax revenue on a particular sale varies depending upon whether a covenant is included in the sale. If a covenant is not a part of the transaction, or if the Tax Court invalidates it for some reason, the seller who has made a profit pays a capital gains tax at the rate of twenty-five percent on the amount that would have been allocated to it, ${ }^{21}$ and the buyer is not allowed a deduction. If there is a covenant, the amount that the seller received for it is taxed at the ordinary income rate ${ }^{22}$ rather than at the capital gain rate, and the buyer is allowed to amortize the cost of the covenant over its useful life. ${ }^{23}$ Assuming that the corporate taxpayers are in the same tax bracket, the additional revenue received because the seller of a covenant pays an ordinary income rate of forty-eight percent, rather than a twenty-five percent capital gains rate, is less than the revenue loss which results from reducing the buyer's taxable income by allowing him totally to amortize the cost of the covenant. ${ }^{24}$

In a sense, the Government is a "silent party" to all business transactions; the protection of its tax revenue is a valid reason for insisting that a covenant not to compete serve a useful business function and is not inserted merely to lessen tax burdens. These considerations of tax policy and of the economic nature of covenants not to compete are important factors in determining whether there should be a right to recover damages for breach of an agreement regarding the tax consequences of a transaction.

There are strong arguments in favor of enforcing the contractual characterizations of such transactions. ${ }^{25}$ The parties have probably bar-

21 Since no money was paid for the covenant not to compete, the sale was only one of capital assets which are taxed at the capital gains rate of $25 \%$. See, e.g., Max J. Epstein, $23 \mathrm{CCH}$ Tax Ct. Mem. 1167, 1169 (1964).

22 See notes 1,13 supra.

23 See notes 2,13 supra. The deduction is permitted because the covenant has a definite life, so that its cost can be amortized over a set period. Treas. Reg. $\$ 1.167$ (a)-3 (1956), as amended, T.D. 6452, 1960-1 CuMr. BuLc. 127. If the deduction was claimed for one year the buyer would not pay any tax on the cost of the covenant. If it is amortized over several years, the deduction of part of the cost each year will reduce the buyer's taxable income by that amount for that year. The total of these yearly deductions will equal the cost of the covenant. In either situation, the total tax revenue from that particular transaction is reduced if the buyer claims a deduction for the covenant. See note 24 infra.

24 This is seen by postulating a situation in which $\$ 100,000$ has been explicitly allocated to the covenant in a sale between corporations. If this amount is not taxed as a covenant not to compete the seller will pay a capital gains tax of $\$ 25,000$. Since the buyer is not allowed a deduction its taxable income will be undiminished, and it will pay the ordinary corporate income tax rate of $48 \%$ on its earnings. This $\$ 100,000$ then will produce $\$ 25,000$ of tax revenue. If it is treated as a covenant not to compete the seller pays the ordinary corporate income rate, or $\$ 48,000$, the buyer is allowed to amortize $\$ 100,000$, the cost of the covenant from its gross income. It pays a tax $\$ 48,000$ lower in the long run than it would have had the covenant not been purchased. In this situation the higher tax paid by the seller is offset by the deduction granted the buyer. Thus, the transaction which does not include the covenant produces $\$ 25,000$ more tax revenue than does the transaction which includes the covenant.

25 These agreements may appear in all contracts in which there is a covenant not to compete and either a reasonable or unreasonable allocation to the covenant. The absence of any allocation in a contract in which a covenant is included may be realistic or unrealistic depending upon the factual situation. Compare note 7 supra. 
gained with the tax consequences in mind and have reached a result acceptable to both sides. As indicated by the Stern case, a breach of this type of agreement will often result in large expense to the other party; when one party to a transaction claims tax treatment which is inconsistent with the other party's claim, both are likely to be involved in litigation with the IRS before the proper tax treatment of the transaction is finally determined. ${ }^{28}$ Even if the nonbreaching party is certain that it has properly assessed its tax liability, the large amount at stake makes it mandatory that experienced, and expensive, ${ }^{2 \pi}$ legal counsel be retained to prepare for the litigation. Providing a right to recover these expenses would seem to be a proper function of contract law so long as such recovery does not frustrate the policies of the tax laws.

These arguments in favor of enforcing all agreements regarding the tax consequences of such transactions proceed from the premise that the parties have bargained at arm's length and have, in fact, reached a definite agreement. Putting aside for the moment the question whether such tax consequences should be a subject of bargaining, there remain many instances in which a contract is ambiguous or silent on a particular point. The parties may have neglected to discuss it or, having discussed it, been unable to reach an agreement and purposely left the contract vague on that point. In either case, both parties are likely to interpret the contract in a light most favorable to themselves and thus claim inconsistent tax treatment. If courts find breaches of agreements in situations where both parties to the contract are able to support different conclusions on the tax treatment to be given the transaction, the threat of contractual liability will tend to deter parties to such ambiguous agreements from pressing arguable claims to favorable tax treatment before the IRS. It is desirable that the courts do not unnecessarily obstruct the attempt, consistent with the revenue laws, of taxpayers to minimize their tax burdens. Moreover, the litigation of competing claims may be the only way of determining the proper tax treatment to be given the particular transaction. ${ }^{28}$ Therefore, courts should

26 There are some cases in which both parties' suits were consolidated in one action: Howard Constr. Co., 43 T.C. 343 (1964); Max J. Epstein, 23 CCH Tax Ct. Mem. 1167 (1964); Bradley J. Broyles, 21 CCH 'Tax Ct. Mem. 1148 (1962); Estate of Leo Melnik, 21 CCH Tax Ct. Mem. 671 (1962), aff'd sub nom. Karan v. Commissioner, 319 F.2d 303 (7th Cir. 1963); Betty W. Crissey, $20 \mathrm{CCH}$ Tax Ct. Mem. 947 (1961) ; Ray H. Schulz, 34 T.C. 235 (1960), aff'd, 294 F.2d 52 (9th Cir. 1961).

Cases in which there were separate suits: Gazette Tel. Co., 19 T.C. 692 (1953), aff'd, 209 F.2d 926 (10th Cir. 1954); Clarence Clark Hamlin's Trust, 19 T.C. 718 (1953), aff'd, 209 F.2d 761 (10th Cir. 1954); Toledo. Blade Co., 11 T.C. 1079 (1948), aff'd per curiam, 180 F.2d 357 (6th Cir. 1950), cert. denied, 340 U.S. 811 (1950); Toledo Newspaper Co., 2 T.C. 794 (1943).

27 The Stern plaintiff was charged over $\$ 20,000$ for legal services performed in contesting the tax deficiencies before the IRS and the Tax Court. 238 F. Supp. at 909. The court held these fees reasonable, $i d$. at 916 , and it is valid to assume that the defendant spent a comparable amount. The Stern legal expenses do not include the fees incurred in bringing the suit for breach of contract.

28 See, e.g., Max Levine, 21 CCH Tax Ct. Mem. 363 (1962), aff'd, 324 F.2d 298 (3d Cir. 1963), in which the seller claimed that the excess of price over book value 
not grant a recovery for a breach of an agreement regarding the tax consequences of a transaction in a situation where a reasonable construction of the contract produces two arguable but inconsistent methods of determining the parties' respective tax burdens. In this situation the right of a taxpayer to contest his tax liability seems controlling.

In Stern the court's finding of an agreement on the tax consequences was based upon the consistent reference to the contract price as the price of the stock and the absence of an allocation of any part of the purchase price to the covenant not to compete. ${ }^{29}$ Standing alone, it would not seem that such evidence could support a specific indication of the parties' intention. Indeed, the lack of a specific allocation of money to the covenant may more reasonably be supposed to have resulted from the failure of the parties to reach agreement on a specific figure than from an agreement that nothing was to be paid for the covenant. However, applying the parol evidence rule, the court construed a precontract letter from buyer to seller as part of the agreement.30 In this letter the buyer stated that Stern would receive capital gains treatment on the purchase price. ${ }^{31}$ Although it could be argued that this letter, written in the early stages of the negotiations, ${ }^{32}$ should not suffice absent a specific disclaimer of an allocation in the final document, the court's reading of the parties' intention was probably correct. It seems clear that State Loan conveyed to Stern the impression that the transfer would be wholly one of capital assets, and thus the court could reasonably have found that the parties had agreed on the tax consequences of the transaction.

There remains, however, the problem of the clear contractual characterization which is contrary to the economic realities of the transaction. An examination of the tax cases dealing with covenants not to compete indicates that parties to the agreement are often unaware of the tax ramifications of the use of a covenant not to compete. ${ }^{33}$ Blanket enforcement of such agreements would deprive parties of the tax treatment to which they are economically entitled in those cases where the contract is not consistent with business reality. ${ }^{34}$ A party, believing that he can reduce his tax liability by claiming tax treatment inconsistent with the contract, is faced with a difficult choice. If he reports his tax liability in a manner

of the tangible assets was paid for goodwill while the buyer claimed this amount was paid for the covenant not to compete. The court recognized the value of each side's claim and split the disputed sum, allocating one-half to goodwill, and one-half to the covenant not to compete.

29. See notes 7-10 supra and accompanying text.

30238 F. Supp. at 912.

31 Id. at 903-04.

32 The letter was sent one week after negotiations began in response to an inquiry by Stern regarding the tax consequences of the transaction. Id. at 903 . It seems unrealistic that an agreement regarding an important part of the sale-a question involving several hundred thousand dollars in tax liability, id. at $914 \mathrm{n.5}$-would be made in this fashion, and that the letter would be the only memorial of that agreement. ${ }^{83}$ E.g., Schulz v. Commissioner, 294 F.2d 52, 55 (9th Cir. 1961).

34 See cases cited notes 15-17 supra. 
consistent with the contract he avoids the possibility of a breach of contract action, but in so doing he waives his claim to the favorable tax treatment to which he is economically entitled. His alternative is to risk being sued for breach of contract by claiming the tax treatment to which he is economically entitled, but which is inconsistent with the contract. In such a case, judging by the Stern analysis, liability would seem to be dependent upon the court's interpretation of the contract terms, and not upon whether the taxpayer was economically justified in claiming the favorable tax treatment. Conceivably a party could prevail in the Tax Court by justifying his claim to the tax treatment even though it was inconsistent with the contract but, in a subsequent contract action, be held liable for the damages that the other party incurred as a result of his action. Consistent with Stern, these damages might include not only the other party's litigation expenses, ${ }^{35}$ but also the difference between the other party's tax burden as determined by the contract and his tax liability as determined by the Tax Court. ${ }^{36}$ The threat of having to pay the extra taxes that were validly assessed against the other party, along with the litigation expenses of both parties in both actions, would effectively deter a party from claiming tax treatment inconsistent with the contract even if he knew his claim to be justified under the tax laws. A wholly contract oriented view would thus deter the litigation of arguable claims. Inevitably, it would allow some parties tax windfalls which are economically unwarranted, deprive other parties of tax benefits permitted under the tax laws, and adversely affect the tax revenue. ${ }^{37}$ Thus the courts should not enforce agreements regarding the tax consequences of transactions when the tax liabilities of the parties as reflected in the contract are inconsistent with the economic reality of the situation.

A counterargument to this conclusion is that the parties have negotiated for a specific result and that the tax benefit was knowingly waived

35 Where one party's action forces another person to protect or defend his interests in court against a third party's claim, the counsel fees incurred in that case are recoverable from the third party.

Cases in which attorney's fees which were incurred in defending tort claims were recoverable from the third party are: General Elec. Co. v. Mason \& Dixon Lines, Inc., 186 F. Supp. 761 (W.D. Va. 1960); Pure Oil Co. v. Geotechnical Corp., 129 F. Supp. 194 (E.D. La. 1955).

Cases in which attorney's fees incurred as a result of a breach of contract were recoverable from the breaching party are: Reichard v. Ezl. Dunwoody Co., $45 \mathrm{~F}$. Supp. 153 (E.D. Pa. 1942) ; Hiss v. Friedberg, 201 Va. 572, 112 S.E.2d 871 (1960). The law in this area is given detailed treatment in Annot., 4 A.L.R. 3d 270 (1965); 5 Corbin, Contracts $\$ 1037$ (1964); Restatement, Contracts $\$ 334$ (1932).

$36 \mathrm{~A}$ recovery from an offending party who caused another to defend against the claim of a third party is not limited to counsel fees, but also includes any judgment that the third party recovered. See Reichard v. Ezl. Dunwoody Co., supra note 35. Thus the extra amount of taxes assessed as a result of the breach could be considered a recoverable item of damages.

37 If a covenant is included in the sale, but the seller is incapable of competing, the seller pays the ordinary income rate instead of the lower capital gains rate on the amount allocated to the covenant, even though it is economically worthless. The buyer gets the benefit of a deduction for the covenant, and the Government receives less tax revenue than it would have had if the transaction had been taxed on the basis of the economic reality of the situation. See note 24 supra. 
in return for other consideration: a buyer, though insisting on a covenant not to compete, might agree not to claim a deduction for it if the seller agrees to a lower sale price. ${ }^{38}$ If there is a breach of this agreement, refusing to enforce it would frustrate the intent of the parties and seem to infringe on the freedom of contract. Furthermore, such a refusal would give the buyer a windfall - he would get both the deduction and the lower sale price. However, such a contract is in effect an agreement by both parties to suppress the real economic nature of the transaction and substitute for it the contract terms. Enforcement of such agreements would constitute tacit judicial approval of the concealment of the true facts of the situation. While allowing the parties to bargain for tax benefits may be advantageous to them, it is clearly contrary to the policy of having taxes assessed on the basis of economic reality. When parties bargain in such a way, they do so with the government's, and hence the public's, money. Further, the courts would have difficulty in distinguishing between those cases in which the tax benefit is waived voluntarily and those in which it is the result of deception or ignorance. Finally, a judicial declaration that such contracts are unenforceable when contrary to economic reality would have the salutory effect of discouraging improper allocations: the hypothetical seller is unlikely to accept a lower price if he knows that his quid pro quo-capital gains treatment-is not an enforceable part of the contract. Thus it would appear that a party's knowing waiver of a tax benefit for other consideration is not a sufficient reason for enforcing such an agreement.

It is suggested that courts should not grant damages for a breach of an agreement regarding the tax consequences of a transaction unless the contract shows a clear, unambiguous statement of the agreement and its contemplated consequences, and it is proven that the resulting tax liabilities are consistent with the economic reality of the transaction.

Assuming the Stern parties' specific agreement, it is difficult to say whether the tax consequences called for in the contract are consistent with the tax laws and with economic reality. A clear disposition of the parties' tax claims by the IRS would be determinative. In Stern, however, the IRS proceedings are not conclusive on this issue becattse neither claim was prosecuted to a final decision. The orders terminating the parties' respective proceedings with the IRS are ambiguous, for there is a possibility that these orders gave inconsistent tax treatment to the same transaction. They permitted Stern to retain capital gains treatment for all of its profits and allowed State Loan to amortize one-fourth of the amount that it had originally claimed as a deduction. ${ }^{39}$ State Loan had made two arguments before the IRS to support its claim to the deduction. ${ }^{40}$ The major conten-

38 This arrangement would be advantageous to the buyer if it had a large loss carryover and did not expect to have taxable income for the year of the sale. The seller could report the sale of a capital asset and not have to pay the ordinary income rate on the amount that he had received for the covenant, thus reducing his tax burden. 39238 F. Supp. at 908 .

$40 \mathrm{Ibid}$. 
tion was that the excess over the book value of the stock was paid for the covenant not to compete. This theory was, of course, inconsistent with Stern's claim that no money was paid for the covenant and is the basis of the breach of contract. The alternative theory was that the loans receivable at the time of the purchase had a value in excess of their face amount because experience showed that loans receivable have an average life of twenty-eight months, and that loan customers renew or refinance them an average of 2.6 times. Since they have a known life they should be deductible. ${ }^{41}$ It is impossible to determine which of the two arguments the IRS accepted. The sum that State Loan was allowed to amortize may have been for intangibles with a known life. On the other hand, the amount is approximately the sum that would be deductible in any one year of the five year life of the covenant. If the deduction was granted on the basis of intangibles with a known life, then the IRS did not permit inconsistent tax treatment of the transaction, for State Loan's deduction would not be related to the covenant or to Stern's claim to capital gains treatment for all of its profits. ${ }^{42}$ In that case the disposition of the competing claims would indicate that the IRS had accepted Stern's claim that no money was paid for the covenant, and that this was consistent with the tax laws and economic reality. If so, then in light of the agreement of the parties regarding the tax consequences of the transaction, ${ }^{43}$ Stern was rightly decided, even applying the suggested standard for enforcing such contracts. However, if State Loan was permitted to take the deduction because of the covenant, then the disposition of the competing claims by the IRS was inconsistent for if State Loan could deduct the cost of the covenant, then Stern should have paid the ordinary income rate on part of the money it received. In this situation, the IRS proceedings would not determine which claim was more consistent with the tax laws and economic reality. Looking then to the facts of the transaction there are strong economic arguments in favor of State Loan's claim to the deduction. The lack of a specific money allocation does not mean that a covenant was not bought and sold. ${ }^{44}$ It absence may be explained by the parties' not being able to agree on a specific figure and deciding to leave the contract vague on that point. Furthermore, the covenant clearly had value, for the customers of Stern's stores were clients of the loan companies; ${ }^{45}$ without the covenant Stern was in a position to destroy the value of the sale by reopening its loan business. State Loan had insisted on the covenant from the begin-

41 This theory was discussed in North Am. Loan \& Thrift Co. No. 2, 39 T.C. 321, 325 (1962), aff'd, 319 F.2d 132 (4th Cir. 1963); United Fin. \& Thrift Corp., 31 T.C. 278,282 (1958), aff'd, 282 F.2d 919, 922 (4th Cir. 1960), cert. denied, 366 U.S. 902 (1961). These cases involved two of defendant's subsidiaries.

42238 F. Supp. at 915 n. 8 .

43 See notes 30-32 supra and accompanying text.

44 See Wilson Athletic Goods Mfg. Co. v. Commissioner, 222 F.2d 355 (7th Cir. 1955) ; Simon Harris, $20 \mathrm{CCH}$ Tax Ct. Mem. 174 (1961); Frances Silberman, 22 T.C. 1240 (1954) ; B. T. Babbitt, Inc., 32 B.T.A. 693 (1935) ; Christensen Mach. Co., 18 B.T.A. 256 (1929) ; 8 Stan. L. Rev. 485 (1956).

45238 F. Supp. at 903. 
ning of the negotiations, ${ }^{46}$ and some of its terms were later modified. ${ }^{47}$ The actual transaction involved the sale of four of Stern's loan companies to four of State Loan's subsidiaries under similar contracts. Only two of these contracts, however, contained covenants not to compete. ${ }^{48}$ The prices paid for these two loan companies and their respective covenants not to compete were substantially higher than the net worth of the corporations while the purchase price of the other two corporations was slightly less than their net worth. ${ }^{48}$ In view of these facts it seems unrealistic to maintain that no money was paid for the covenant.

If the IRS's disposition of the competing claims was inconsistent, then in light of the facts surrounding the transaction, it would appear that the economic realities would favor State Loan's claim to the deduction. Thus even though the court could find an agreement to the contrary regarding the tax consequences of the transaction, any contract suit for damages for breach of that agreement should not be enforced because of the policy against encouraging the bargaining for tax benefits.

This proposed solution places emphasis on the IRS's and the Tax Court's disposition of the competing claims because those are bodies charged solely with the enforcement and interpretation of the tax laws, and they are more proficient in handling the complex matters and economic issues in tax litigation. Furthermore, if the contract courts adopt the findings of the IRS and the Tax Court and use the same criteria, the results in contract cases will not be contrary to the tax policies.

The proper disposition of the Stern case under the proposed requirements for the enforceability of such agreements would depend upon whether or not the IRS permitted inconsistent tax treatment of the transaction. Unfortunately the Stern court did not examine this question. ${ }^{50}$ If courts are faced with the same ambiguous situation in the future it is suggested that the better decision would be to insist upon strong evidence that the plaintiff's position is supported by the economic reality of the transaction before granting a recovery.

46 Ibid.

47 Compare id. at 904-05, with id. at 906-07.

$48 \mathrm{Id}$. at 906-07.

49 Defendant's Brief in Reply to Plaintiff's Brief in Opposition to Motion To Dismiss Complaint, pp. 18-19.

50 This conclusion [that State Loan claimed tax treatment inconsistent with Stern, and if it was permitted that it would result in the disallowance of Stern's capital gains benefits] is not negatived by the fact that the asserted tax deficiency against plaintiff was dismissed by stipulation, while at the same time the Government, [sic] allowed defendant's subsidiaries to amortize $25 \%$ of the amount by which their payment to plaintiff exceeded the book value of the assets of the loan companies. This latter action was the result of a stipulated settlement, and may well have reflected the Governments acceptance in whole or in part of an alternative argument that the defendant urged which was supportable without reference to the covenant not to compete.

238 F. Supp. at 915. 